\title{
Tobin Tax in Reducing the Negative Effects of Capital Controls and Short Termed Capital Movements
}

\author{
Ph.D. Candidate Rahime Hülya Öztürk (Selçuk University, Turkey) \\ Assoc. Prof. Dr. Zeynep Karaçor (Selçuk University, Turkey) \\ Ph.D. Candidate Perihan Hazel Er (Selçuk University, Turkey)
}

\begin{abstract}
The phenomenon liberalization, with the influence of Bretton Woods system that collapsed, following 1970 Oil Shock, first began with the efforts to search for the markets to value the investments of these countries in the developed countries. When arrived to 1980s, the developed countries, squeezed under the debt load accompanying the insufficient capital accumulation and low saving rates, in order to provide the desired capital figures, needed the foreign resources and, in this point, liberalization process of capital gained importance In realizing the growth and developmental targets of country economies, their integrating to liberalization process have a great importance. That the developing counties integrate to the system without the necessary arrangement in their financial structures made an effect in the direction of disturbing the stability of country economies, particularly in short termed capital inflows. As much as the problem created by the speculative capital inflow, the immediate outflow of this capital, disordering the balance of country economies, also caused crises. For maiming the negative influences of short termed capital, capital controls are emphasized. Just as these controls can have the various application ways, the most emphasized and discussed application was Tobin tax. Even though there are the various disagreements in the direction of whether or not Tobin tax affected the capital inflows, the examples of Malaysia and Chili gave the successful results.
\end{abstract}

\section{Introduction}

Together with the Second World War, the countries adopting the principle of capital controls of Breton Wood System, also with the effect of Oil shock in 1971, following the collapse of system and emergence of stagflationist tendencies, started the applications in the direction of removing the controls in the capital. This situation caused the globalization movement to gain acceleration and the liberalization process to form. In this period, the economic depression and debt crises the developed countries are in led these countries to adopt the financial liberalization for getting out the recession with also the effect of the financial agencies such as IMF and World Bank (Kara and Kar, 2005:96). With the liberalization policies applied, firstly, the limitations on the domestic financial markets were removed, and then, the limitations on the capital movements (Keskin, 2009). With removing of limitations, the countries rapidly integrated to the system, however, in the developing countries integrating to the system without making the necessary arrangements in their financial markets, capital inflows disturbed the stability of economy. Financial capital movements can lead to the fluctuations in the variables such as exchange rate used by central banks as main or sub-target, foreign currency reserves, monetary magnitudes, and inflation and make ineffective the monetary policy (Hoggarth and Sterne, 1997). While the capital flows going toward the developing countries satisfy the need for resource of countries, the immediate inflows and outflows of capital increased the vulnerability of country economies. In many developing countries, 1990s, when the financial liberalization movements gained acceleration, became a period, in which the important increases in the international capital movements actualized and also the severe crises were experienced, that emerge in frequent intervals and can spread easily ( Bedestenci and Kara,2004; Işık, 2005). The crises experienced led the policies supporting the marketization of the country economy to be reasoned and the views supporting the necessity of the alternative policy applications to emerge (Ay and Mangir, 2007).

The major alternative policy applications are the capital controls. In terms of effectiveness of capital controls, there is no consensus in the literature. According to the economist considering that capital controls are positive, if due to s speculative attack, a problem in the balance of foreign payment is faced and the existing arrangements cannot cope with this problem, appealing to the capital control may be a solution. The examples of Malaysia and Chili is successful in this meaning. According to the economists emphasizing the negative effects of capital movements, these controls, retarding the structural reforms, cause the existing crocked economic relationships to last. In addition, it is considered that these controls will not be effective via the derivative markets (Ankara Sanayi Odas1, 2001).

Among the policy applications suggested, the most remarkable one was Tobin tax, put forward by Tobin. This tax, is ad valorem tax, which, in the first studies of Tobin, was brought into the spot foreign currency buying systems, is considered to be between $0.1 \%$ and $0.5 \%$, and in his next studies, which can be expressed that it can rise until 1\% (Y1lmaz, 2004). 


\section{Capital Controls}

Capital controls is the official arrangements affecting the international capital movements (Vergil, 2002). Capital controls, implemented in the extraordinary situations such as 1st World War, Great World Depression, and 2nd World War, following the last war, in both Eastern and many Western counties, together with becoming popular of central economy, it became one of the main instruments of the economic policy (Keskin, 2009). International capital flows enter and go out the national economy through very different ways and the uncertainty and risky environment form an appropriate environment for the capital controls. Against these negative economic effects resulted from the capital movements, capital controls are every kind of policies the country applied, in order to limit the transactions of capital account or direct (Neely,1998 ). The especially remarkable and discussed application in capital controls is Tobin tax.

Magud and Reinhart (2007) define the four fears for capital controls.

- The fear about valuation of exchange rate.

- The fear of "hot currency"

- The fear of high volume capital inlet

- The fear of that the independency of monetary policy will be lost

Johnston and Tamisira (1998) put in order the reasons for capital controls as follows.

- Payments balance and macro management

- Market and institutional evolution

- The cautious policies

- The size and openness of economy

Capital controls are emphasized in two ways, directly and indirectly.

In direct capital controls, direct limitations are brought into the capital transactions and payments related to these transactions, and transfer of funds via the apparent prohibitions, quantity limits, and approving mechanisms. The limitations about the relevant sort of capital are carried out by imposing on the banking sector (Ariyoshi et al, section 1, box 1, 2000).

Indirect capital controls are preventing the capital inflows by increasing the costs of financial transactions providing the capital movements. They are applied as multiple exchange rate system, open taxation, indirect taxation.

Multiple Exchange Rate System: In dual exchange rate systems, for the transactions of current account such as import and export and for the transactions of capital account forming as a result of capital flows, the different exchange rates are applied. Multiple exchange rate system is generally applied during the crises of payments balance. While the part of this system running in the way of fixed exchange rate is protecting the trade operations from the movements of exchange rate, its part running in the way of floating exchange rate system, moving according to the supply and demand in the market, provides the economic sectors with flexibility in the applications of monetary policy (Fan, 2004).

Open taxation (Tobin tax): In this application, it is obligatory for the bank or non-bank financial agencies to hold the foreign currency that equals the determined rate of net exchange position or capital that equals to the domestic currency equivalent of this total in the central bank of country without interest. This kind of control is applied to both capital inflows and capital outflows.

The application difficulties of capital controls can be put in order as follows.

- If the capital coming to country is reported as a sort of capital to that the control are not applied, it means to bypass the relevant controls.

- In the capital control, as the tax rates, time to hold capital, and exception number increase, the complexity of the system also increases.

- It is necessary to continuously update the content of capital control application, in order to prevent from bypassing the control; however, this situation increases the costs of applications (Kokenyne et al, 2010).

- Since capital control significantly affected the system, it causes the financial system to slow during application:

Capital controls are used as an instrument in preventing the financial crises. For preventing the formation of crises, the different polices are also applied.

\section{The Policies Applied for Preventing the Emergence of the New Crises}

From the view point of not emerging of the new financial crises or not becoming deeper the crises that may arise, the actions to be able to take in the foreign currency market can be discussed under the following headings (Birinci, 1998). 
- Taxing the transactions (Tobin Tax)

- Fixing the exchange rates or determining the limits of exchange rate

- Application of multiple exchange rate

- Increasing the international banking audit, impeding the capital escape

- Trading halts applications (closing the transactions markets in the crisis environment)

- Establishing the international alarming system

- Increasing IMF quotas

- IMF warranted borrowing easiness

- Organizing the financial movements in the framework of a process similar to GATT

- Target zone system (via international cooperation, preventing the unrealistic exchange rate variations).

The other suggestions are (Eğilmez, 1999: 41);

- Transforming Interim Committee (Interim Committee of The IMF) into the executive council

- Bounding the international system to the rules that ate in international validity

- Transforming G-7 into a decision body in the form of G-15, including the developing countries (J.Sachs, 1999)

- Rescuing IMF from the press of USA Treasure, restoring an independent structure (J.Sachs, 1999 )

- Completing the financial sector reports in all countries

- For the struggle with corruptions and better and transparent public administration, making worldwide attempts

- Establishing an international debt panel, enabling the various countries to perform their debt reliefs through this panel

In reducing the negative effects of capital flows, the alternative policy applications are putt in order as follows;

- $\quad$ sterilization of capital flows

- application of more flexible exchange rate

- capital controls

- tight fiscal policies

- tightening the monetary policy in response to capital escape

- fortifying the banking system

\section{In Reducing the Effects of Short Termed Capital Movements, May Tobin Tax Be a Solution?}

Global capital movements are examined as indirect investments, short termed monetary capital, central and fiscal funds, speculative fund flows, and laundering the money.

Foreign capital investments are collected in two groups. One of them is the portfolio investment, in other words, hot money; the second is capital to be brought in the way that it will increase the production capacity of country. Portfolio investments are short termed. This kind of investments very rapidly leave the country at the moment of a crisis and become deeper the dimension of crisis (Acar, 2003).

When the controls are removed on the capital movements, there occurs a capital inflow toward the developing countries. The reason for this, with the rise of interest rates in the developing countries, is that they rise up average of the world. Since this also means a profitable investment for the foreign investors, a capital flow occurs toward the developing countries. The relationship between the short termed capital movements and exchange rate occupies an important place in shaping of financial crises. In the conditions of floating or free exchange rate or in the conditions of fixed exchange rates exposed to often changes, it is possible to avoid the risk of foreign exchange. If one can avoid the risks of foreign exchange, the short termed capital movements cannot occur. Since the risks of foreign exchanges are consciously undertaken, when the short termed capital movements occur, these provide the stability and become an element of instability (Kindleberger, 1970).

Capital flows becoming free, under the press of the profit rate to fall, provides the capital escaping from its own land with higher return. In the counties it goes, especially in the developing countries, whose financial markets are vulnerable, it becomes source of a great fiscal instability, accelerating the speculative movements, leads to the crises.

Interest arbitrage includes very short termed capital movements and portfolio investments, because, theoretically, the differences between international interest rates domestic interest rates largely cause the short termed capital movements (Iş1k-Duman-Korkmaz, 2004: 59).

There are three main features of speculations. First is that there is a descent of a rise and that speculative rises conclude with a collapse. The second one is that there are losers in response to the winner and in a general sum, is that the case that no income can be created via speculation. The last is, in the real production sectors, when the profitability rate of capital decreases, that the speculations gain intensity and that demands for fund is created. 
Black money, very generally, is the value of every kind of property, expressed income and money obtained by offending. The identity and citizenship of the funds that enter and leave the countries in the form of fluid funds is uncertain. Liberalization of capital movements accelerated the formation of black money. Some part of unrecorded economy is related to the common but local practices of the recorded firms such as tax evasion, not paying for social security premium, and understating the number of wage of workers. Some part of it consist of the crimes such as arms smuggling, drug trafficking, terror financing, and winning international tender by corrupting, in which the people of a number of globalizing country are included. The size of its dimensions made a current issue that these black money sourced funds must absolutely find a way to gain favor and to be cleaned and the important role in the financial crisis especially experienced in the developing countries (Kazgan, 2005).

In 1972, James Tobin, in his book, in order to reduce the negative effects of short termed capital movements, gave place a suggestion. This suggestion is that a single type of transformation tax that will be collected in the spot markets, where a foreign currency is converted to another one, will prevent the circulation of short termed capital movements. As far as James Tobin disturbed that international transaction tax, suggested by himself turned into opposition to globalization, this precaution placed in the first rank of the suggestions about impeding the short termed capital movements (Akdiş, 2004). Tobin suggests that the tax offered by him should be applied to all financial instruments. According to Tobin, this tax should be applied in in case that a currency unit purchases the good, service, and real estate in the region, where another currency unit is valid, This offer of Tobin identifying with the words of "throw sand in the wheels" includes to impose tax to the short termed and high summed capital movements that disproportionally actualize in the global exchange rate markets (Westerhoff, 2003: 2). James Tobin suggested to apply a tax that includes foreign currency exchange and that will affect all international foreign currency transactions. The tax of interest will come into play in both buying and selling whatever the aim of transactions is. At the beginning, it was considered that this tax should be applied in only current market, but the multiplicity of dodges in the current market revealed that the tax should encompass all markets (Ciritçi, 2004: 57).

\begin{tabular}{|c|c|c|c|c|}
\hline Countries & Year & Reason & $\begin{array}{l}\text { Control mechanism of capital } \\
\text { movement }\end{array}$ & Results \\
\hline $\begin{array}{l}\text { Europe } \\
\text { and Latin } \\
\text { America }\end{array}$ & 1929 & $\begin{array}{l}1929 \text { Economic } \\
\text { depression }\end{array}$ & Foreign currency controlled & Successful \\
\hline $\mathrm{ABD}$ & 1960 & $\begin{array}{l}\text { Depending om the } \\
\text { tendencies, in the } \\
\text { direction of liberalization, } \\
\text { that capital outflows are } \\
\text { experienced }\end{array}$ & $\begin{array}{l}\text { Levying the tax on the capital } \\
\text { outflows - tax on equalizing the } \\
\text { real interest rate }\end{array}$ & $\begin{array}{l}\text { Partially successful } \\
\text { (It has no } \\
\text { remarkable effect } \\
\text { in reducing } \\
\text { speculation ) }\end{array}$ \\
\hline Israel & 1996 & $\begin{array}{l}\text { Limitation of capital } \\
\text { inflows to the country }\end{array}$ & $\begin{array}{l}\text { Levying the tax on the capital } \\
\text { inflows }\end{array}$ & $\begin{array}{l}\text { Partially successful } \\
\text { (It has no } \\
\text { remarkable effect } \\
\text { in reducing } \\
\text { speculation ) }\end{array}$ \\
\hline Malaysia & 1998 & 1997 Asia Crisis & $\begin{array}{l}\text { The controls made on the } \\
\text { outflows of capital - limitation } \\
\text { of Malaysian citizens to invest } \\
\text { capital abroad and stopping the } \\
\text { inlet of foreign investments for } \\
12 \text { months }\end{array}$ & Successful \\
\hline Chili & $\begin{array}{l}1978- \\
1982 \\
1991- \\
1998 \\
\end{array}$ & Banking Crises & $\begin{array}{l}\text { Controls on capital inflows - } \\
\text { imposing the non-profit reserve } \\
\text { deposit obligation om the } \\
\text { portfolio investments }\end{array}$ & Successful \\
\hline Brazil & 1998 & 1997 Asia Crisis & $\begin{array}{l}\text { Control of capital outflows - } \\
\text { transaction tax - imposing } \\
\text { General Transfer tax om banking } \\
\text { transfers in the rate of } 0.25 \%\end{array}$ & Unsuccessful \\
\hline
\end{tabular}

Table 1. World applications toward controlling the capital movements in the selected countries, World applications toward controlling the capital movements in the selected countries, Source: Fatih Mehmet Citations in the text Öcal, 2012

It is considered that Tobin tax is collected through the transactions of foreign currency exchange in a single and very low rate according to ad volerem base. Tobin himself these can be in the rates of such as $0,2 \%, 0,5 \%$, and $1 \%$. Tobin, suggesting that the financial crisis rising in Asia demonstrated how volatile foreign currency 
exchange system is, expressed that a global tax to be able to levy through foreign currency exchange is one of the probabilities to solve the problem of excessive volatility (Akdiş, 2004). Provided that the scope of Tobin tax can be extended in such a way that it will include at least the markets of future options and swap, it will always be possibilities to avoid this kind of taxes. When compared to the development of spot markets, the derivative markets, in the recent years, show a rapid development all over the world. This situation forms a reason for including the derivatives transactions in the scope of tax. When the tax is imposed, with the thought that the new financial instruments can be invented, which are not included in the scope of tax, it will be necessary to extend the scope of tax in such a way that it will include the sorts of security and derivatives market instrument to be able to emerge further (Y1lmaz, 2002: 9 ). In the application of Tobin tax, the transactions of foreign currency exchange of national states, central banks, and international official organizations and very small sized transactions are exempted from Tobin tax (Patterson and Galliano, 1998: 29). In addition, the regions of monetary union is in the scope of exemption.

In Table 1, a summary of capital control applied in the world is presented. According to the Table, the applications of Malaysia, Chili, Latin America countries, and Europe became successful, Brazil successful, and USA partially successful

\begin{tabular}{|c|c|}
\hline Supporters & Opponents \\
\hline $\begin{array}{l}\text { That it brings the stability to the international finance } \\
\text { market, preventing the speculative monetary } \\
\text { movements }\end{array}$ & $\begin{array}{l}\text { With that it serves as a short termed monetary policy } \\
\text { instrument, that it is not an effective instrument in } \\
\text { eliminating the economic instability }\end{array}$ \\
\hline $\begin{array}{l}\text { With the struggle with instabilities the speculative } \\
\text { capital led to, its fortifying the internal resources of } \\
\text { the country }\end{array}$ & $\begin{array}{l}\text { Its negatively affecting the development of financial } \\
\text { markets in the developing countries }\end{array}$ \\
\hline $\begin{array}{l}\text { With reducing the rate of Tobin tax according to the } \\
\text { maturity, encouraging longer termed foreign capital }\end{array}$ & $\begin{array}{l}\text { With that the short termed capital leaves the country, } \\
\text { increase of budgetary deficits }\end{array}$ \\
\hline $\begin{array}{l}\text { Obtaining tax income and using this income for } \\
\text { regulating international markets }\end{array}$ & $\begin{array}{l}\text { Since Tobin tax, depending on the technical and } \\
\text { political differences, cannot be simultaneously applied } \\
\text { by all countries, that the foreign capital goes toward } \\
\text { the tax-free transactions and the countries that ate tax } \\
\text { heaven }\end{array}$ \\
\hline $\begin{array}{l}\text { With preventing the speculative capital movements, } \\
\text { providing the stability in exchange rates and interest } \\
\text { rates }\end{array}$ & $\begin{array}{l}\text { Since Tobin tax does not satisfy the expectations of } \\
\text { governments in case that the lower tax base forms, the } \\
\text { fact that the tax incomes below that hoped }\end{array}$ \\
\hline $\begin{array}{l}\text { That IMF and World Bank provide the resource for the } \\
\text { international stability programs and solution of social } \\
\text { problems of the world }\end{array}$ & $\begin{array}{l}\text { The thought that the taxes to be applied toward the } \\
\text { capital movements will deviate the financial markets; } \\
\text { direct the investors; and keep the financiers out of the } \\
\text { economy and sector or shift them to the regions } \\
\text { exempted from tax }\end{array}$ \\
\hline $\begin{array}{l}\text { Together with the increase of short termed capital } \\
\text { transactions, making the foreign investments in the } \\
\text { long period, and depending on this, stimulation of the } \\
\text { real sector }\end{array}$ & $\begin{array}{l}\text { That makes the variable tax rates, tax accountabilities, } \\
\text { and responsibilities on the tax administration } \\
\text { complicated and that such a tax imposed om the } \\
\text { capital movements reduces the effectiveness in the } \\
\text { market }\end{array}$ \\
\hline $\begin{array}{l}\text { Inserting the transactions of multinational companies } \\
\text { that are left out of tax to the scope of tax in an } \\
\text { international platform }\end{array}$ & $\begin{array}{l}\text { In case that with tax, the short termed capital } \\
\text { movements decrease, constriction of trading volume; } \\
\text { and with increase in the volatility, that exchange rate } \\
\text { cannot realize the commercial gains }\end{array}$ \\
\hline $\begin{array}{l}\text { With Tobin tax, that the governments are rid of the } \\
\text { press on the country currency and that they can more } \\
\text { easily the economic policies }\end{array}$ & $\begin{array}{l}\text { That the size of additional charge to be put on the } \\
\text { transactions is not well calculated and depending om } \\
\text { its high taxing, its raising the transaction costs and } \\
\text { reducing the trading volume; and its negatively } \\
\text { affecting the long termed investment }\end{array}$ \\
\hline
\end{tabular}

Table 2. The views on Tobin Tax, Source: Fatih Mehmet Öcal, 2012

In an alternative way to Tobin tax, some polices are suggested. These are:

- Taxing Foreign Securities

- Taxing the Capital Inflows and Outflows

- $\quad$ Taxing the Capital Gains

There are some points that are dominant in the application of Tobin tax. These are: /Patterson and Galliano, 1998: 29) 
1. As the number of foreign currency exchange transactions increases, the effective tax rate increases.

2. Tobin tax will not make all speculative transactions non-profit and impossible and will only raise the rate of risk.

The possible benefits of Tobin tax (Halifax, 2003)

- With the decrease of transaction volume in the foreign exchange markets, the volatility of foreign currency will fall and stability will mobilize the trade of goods and services.

- This tax will provide a financial support in the runs between economies. The possible damages of tax are put in order as follows.

- Application of such a tax serves as an instrument of only short termed monetary policy (Spahn, 1996: 8)

- For being able to apply a tax, it will be necessary to make an agreement with each financial center in the world; otherwise, the foreign currency markets will go toward the tax -free transactions and the countries, tax heaven (Raffer, 1998: 534). That such a tax is simultaneously executed by all countries is not applicable from the technical and political point of view (Edwards, 1999: 2).

- Applying such a tax will bring a bureaucratic charge to the market, in which $\$ 1-1.5$ million is revolved.

- Another issue is that taxing the foreign currency transaction will be able to switch the direction of international capital to the derivatives markets and it will go toward the commercial papers and acceptance of banker (Spahn, 1996:2).

- If the exchange rate is face to face with the speculative stocks, speculators, considering the tax charge on the transactions they carried out, will move and this will be able to increase the volatility rather than reducing.

In the literature, there are some views supporting and opposing Tobin tax. Table 2 includes the views on Tobin tax.

\section{Conclusion}

Integration of financial markets and the developing countries are caught unpreparedly to this integration made the country economies vulnerable. Especially, using the short termed capital movement with the speculative purposes increases this vulnerability and creases an effect disturbing the financial stability. For reducing the vulnerabilities of economies and making them less sensitive against the capital movement, a lot of precautions were emphasized. The major one among these precautions is capital controls, while in the capital controls, the most emphasized and discussed was Tobin tax.

James Tobin suggests an ad valorem tax in order for the capital to stay for long term in the county it entered. This tax expresses a lower rate such as $0.2 \%, 0.5 \%$, and $1 \%$. This tax of lower rate, when considering the size of trading volume, corresponds to a large amount in the way of not being able to ignore.

Malaysia and Chili, with the limitation they bought to the inflows and outflows of capital, managed to provide the financial stability. The tax does not affect the long termed capital outflows and only aims to constrain the short termed capital inflows. The major criticism brought to Tobin tax is bureaucratic charge and international capital that will go toward derivatives markets. The economic crises experienced by the developing countries showed that that the economies include in the financial markets without making the necessary preparations makes an effect disturbing the stability. What should be done is to include in the financial system without disturbing the economic stability. The way of realizing this is that the financial markets become deeper and develop. If it was integrated to the system without providing this deepening and development, the vulnerability of economy becomes unavoidable and it is moved to the searches reducing the vulnerability. The capital controls are the leading one of these searches. The capital controls stand out as an important instrument in reducing the effects of capital movements.

\section{References}

- Acar, 2003. “Dolaysız Yabancı Sermaye Yatırımları”, Vergi Dünyası, Sayı: 265.

- Ankara Sanayi Odas1, 2001. Malezya Sermaye Kontrolleri.ASOMEDYA DergisiAğustos 2001.

- Akdiş, "Kısa Vadeli Sermaye Hareketlerinin Yol Açtığı Finansal Krizler ve Bu Krizleri Önlemede Kullanılabilecek Araçlar: Tobin Vergisi", Active Bankacılık ve Finans Dergisi, Yıl: 6, Sayı: 36, (MayısHaziran/2004), s.36-48.

- $\quad$ Ariyoshi, Habermeier, Laurens, Ötker-Robe, Canales-Kriljenko, Kirilenko, 2000. “Capital Controls: Country Experiences with Their Use and Liberalization” IMF .Özel Durum .Çalışması, 190. http://www.imf.org/external/pubs/ft/op/op190/index.htm

- Ay, Mangır, 2007.Uluslararası Finansal Entegrasyon Bağlamında SermayeninVergilendirilmesi: Tobin Vergisi Maliye Dergisi Sayı 153 Temmuz-Aralık 2007,ss 123. 
- $\quad$ Bedestenci, Kara, 2004.Sermaye Hareketleri ve Kalkınma .Sami Taban ve Muhsin Kar (der).Kalkınma ekonomisi Seçme Konular içinde, Ekin Kitabevi, Bursa.

- Birinci, Yüksel, 1998. "Döviz Piyasası İstikrarına Yönelik Öneriler”, Banka ve Ekonomik Yorumlar Dergisi, Y1l:35, Say1:1, (Ocak-1998), s.19-29.

- Ciritçi, 2004. "Kısa Dönemli Sermaye Hareketleri ve Finansal Krizler Arasındaki İlişki Bağlamında Tobin Vergisi”, Marmara Üniversitesi, Yüksek Lisans Tezi.

- Eğilmez, Mahfi 1999, “Global Finansal Kriz ve Türkiye’ye Etkileri”, MESS Mercek Dergisi, Özel Sayı, Ocak-1999, s.33-43.

- Fan, 2004. “A Note on Dual/Multiple Exchange Rates”. ERDv Policyv Brief.No.26,ç Asya Kalkınma Bankas1. http://www.adb.org/Documents/EDRC/Policy_Briefs/PB026.pdf.

- Franklin, Liew, 1999. “Journal of Futures Markets”, Volume 19, Issue 4, pages 377-411, June 1999.

- Halifax Iniative 2003. "The Tobin Tax: An international tax on foreign currency Exchange”, http://www.halifaxinitiative.org/hi.php/tobin/70

- Hoggart,G. And Sterne, G.1997.Capital Flows: Causes, Consequences and Policy Responses.London.Central of Central Banking Studies No: 14 Bank of England.

- Işık, Duman, Korkmaz 2004. "Türkiye Ekonomisinde Finansal Krizler: Bir Faktör Analizi Uygulaması”, D.E.Ü.İ.̇̇.B.F. Dergisi, Cilt: 19, Sayı: 1, 2004.

- Johnston, Tamirisa, 1998. “Why Do Countries Use Capital Controls?”. IMF.Çalısma Tebliği.98-181.G http://www.imf.org/external/pubs/ft/wp/wp98181.pd

- Kar, Kara, 2002. “Türkiye’ye Yönelik Sermaye Hareketleri ve Krizler”, Dış Ticaret Dergisi, Sayı: 29, Temmuz 2002, ss. 13-80.

- Kazgan, 2005. “Küreselleşme ve Ulus-Devlet Yeni Ekonomik Düzen”, İstanbul Bilgi Üniversitesi Yayınları, İstanbul.

- Keskin, 2009. Sermaye Kontrolleri: Nedenleri, Türleri ve Ülke Deneyimleri. Sosyo Ekonomi 2009.

- Kındleberger, 1970. "Uluslararası İktisat”, (Çeviren: Nedret Serin), Doğan Yayınevi: 10, Özel Dizi:1, Ankara.

- $\quad$ Kokeyne, Nowak, Psalida Sun, 2010. Global Liquidity Expansion: Effects on Receiving Economies And Policy Response Options. IMF.Küresel Finansal İstikrar Raporu. http://www.imf.org/external/pubs/ft/gfsr/2010/01/pdf/chap4.pdf

- $\quad$ Magud, Reinhart, Rogoff, 2007. "Capital Controls: Myth and Reality, A Portfolio Balance Approach to Capital Controls”., Federal.Reserve.Bank.of.San.Francisco Çalısma Tebliği. http://ideas.repec.org/p/ore/uoecwp/2006-10.html

- Neely, C. J. 1999. An Introduction to Capital Controls, Review, Federal Reserve Bank of St Louis, November/December 1999, 81 .6. https://research.stlouisfed.org/publications/review/99/11/9911cn.pdf.

- Ö̈al, Polat, 2012. "Küresel Düzeyde Sermaye Hareketlerini Yönetmede Tobin Vergisi: Türkiye Örneği "Erciyes Üniversitesi İktisadi ve İdari Bilimler Fakültesi Dergisi, Sayı: 40, ss. 67-94.

- Patterson, Ben- Galliano Mickal, 1998. "The feasibility of an international "Tobin tax", Directorate General for Research, European Parliament, March, 1998.

- $\quad$ Radelet, Sachs, 1999. What Have We Learned So Far From The Asian Crisis? Office Of Emerging Markets, Economic Growth Center, CAER 2 Project, Delivery Order no: 16.

- Raffer, Kunibert, 1998 "The Necessity of International Chapter 9 Insolvency Procedures", in: Eurodad (ed), pp.25ff

- Sermaye Hareketlerinin Kontrolü ve Özel Yatırım Üzerine Etkileri Hasan Vergil Kocaeli Üniversitesi Sosyal Bilimler Enstitüsü Dergisi (3) 2002/1: 19-33.

- The Tobin Tax and Exchange Rate Stability PAUL BERND SPAHN. https://www.imf.org/external.

- Westerhoff, 2003. "Heterogeneous Traders and the Tobin tax", J Evol Econ, Springer-Verlag, 13.

- Yılmaz, Celali, 2002. "Döviz kuru istikrarının sağlanmasında vergi politikasından yararlanılması: Tobin vergisi”, Active Finans Dergisi, Sayı: 24, Mayıs-2002.

- Yılmaz, Celali, 2004. Döviz Kuru İstikrarının Sağlanmasında Vergi Politikasından Yararlanılması: Tobin Vergisi. Geleneksel Finans Sempozyumu 2004 Bildirileri. Marmara Üniversitesi Bankacılık ve Sigortacılık Enstitüsü \& Bankacılık ve Sigortacılık Yüksekokulu. 